\title{
Integrated reporting by South African companies: a case study
}

\author{
Elda du Toit* \\ Department of Financial Management; University of Pretoria; Pretoria; South Africa
}

\author{
Renier van Zyl \\ Department of Financial Management; University of Pretoria; Pretoria; South Africa
}

\author{
Gina Schutte \\ Department of Financial Management; University of Pretoria; Pretoria; South Africa
}

${ }^{*}$ Corresponding author: Elda du Toit

elda.dutoit@up.ac.za

\section{ABSTRACT}

Investors and stakeholders rely on high-quality integrated reports to obtain social, environmental and ethical information for decision-making. A striking weakness found in recent research on integrated reports is the way certain items of social, environmental and ethical information are excluded while other items are repeated. There is accordingly much confusion, clutter and fragmentation in the integrated reporting landscape. There are as yet no reports on the long-term effect of mandatory integrated reporting on the quality of information. Through a detailed content review of the information companies report on, more insight can be gained into this question five years after the mandatory implementation of King III, which requires companies to provide integrated reports. The study used a similar approach to that of Solomon and Maroun (2012), reviewing the integrated reports of four companies with high social and environmental impact, over a period of three years (2012 to 2014). The companies' integrated reports were reviewed in terms of social, environmental and ethical items. The results indicate that there has been a distinct decrease in the amount of information provided in integrated reports but, more importantly, there still exists significant uncertainty as to the amount of reporting that is required. The results of this study provides evidence that regulators may have to provide more detailed guidelines as to the reporting duties of companies. It also indicates to 
managers that their approach to integrated reporting may have to be revised to ensure useful information is provided to stakeholders.

Key words: Corporate governance, Financial reporting, Corporate social responsibility, Content analysis, Integrated reporting, Qualitative research

\section{Introduction}

The past five years have seen a dramatic shift in the development of integrated reporting around the world (Atkins, Solomon, Norton \& Joseph, 2015). Integrated reporting is about the promotion of integrated thinking, as well as improving stewardship and accountability (IIRC, 2013a; Stent and Dowler, 2015). However, integrated reporting has not been an immediate success and it will take some time for the process to be completely established and accepted (Atkins and Maroun, 2015).

A study by Solomon and Maroun (2012) indicated a significant increase in the amount of integrated reporting from 2009 to 2011. However, there were still considerable weaknesses, especially in the form of repetition throughout the reports. This paper seeks to assess the extent to which integrated reporting practices changed from 2012 to 2014 in comparison to the 2009 to 2011 period as the integrated reporting environment developed. The motivation for the study is based on a growing interest in and importance for integrated reporting, which still requires scholarly input.

Eccles and Armbrester (2011) claim that integrated reporting is the best way for an organisation to illustrate its ability to create long-term value to investors and other stakeholders. Additional information pertaining to companies' social, environmental and governance activities, as well as investments can provide useful information about the value of companies' intangible assets (Serafeim, 2015), since many companies' market value exceed their book value by a wide margin. Integrated reports therefore provide investors and stakeholders (specifically decision makers such as potential customers and prospective employees) with information pertaining to a specific organisation's strategies, longer-term prospects and its vision (Ighian, 2015). 
During the past two decades there has been an increased tendency amongst companies to separate social and environmental disclosures into distinct, stand-alone reports. This practice has become more complex as companies have to report on a greater range of issues to meet the increasing expectations of stakeholders. Following this, initiatives have been launched to combine the social and environmental reports again into a single report (De Villiers, Rinaldi, \& Unerman, 2014). There were numerous companies that issued integrated reports even before the original integrated reporting framework was introduced (Eccles \& Serafeim, 2011). South Africa, however, is considered the pioneering country when it comes to formalised integrated reporting, as it played a pivotal part in driving the implementation of integrated reporting to where it is today. To stay at the forefront of corporate governance, the King III report required all 400 companies listed on the Johannesburg Stock Exchange (JSE) to prepare an integrated report with effect from March 2010 on a comply or explain basis (EY, 2014).

Another factor contributing to the growing preference for integrated reporting is the dramatic increase in moral requirements imposed on companies due to an increase in the social impact of companies' activities, both on the economy and the communities in which they operate. As the size of companies and the impact of their activities on communities increase, their moral obligations tend to appreciate commensurately. This phenomenon is known as corporate social responsibility or CSR (Ighian, 2015). In terms of King III, companies need to report on both positive and negative aspects with regard to the impact of their activities, and how they plan to enhance the positive and eradicate the negative (Eccles \& Saltzman, 2011). There are still numerous companies listed on the JSE that do not prepare integrated reports or neglect to report on critical issues. During $2013,50 \%$ of companies listed on the JSE prepared integrated reports, while many had to explain their reasons for failing to do so (Frías-Aceituno, Rodríguez-Ariza \& García-Sánchez, 2013).

Studies have been conducted on the quality of integrated reports, with PricewaterhouseCoopers $(\mathrm{PwC})$ specifically conducting a survey on the top 50 companies in the Netherlands to determine the quality of their integrated reports (De Villiers et al., 2014). In South Africa, PwC conducted the same study on the top 40 JSE-listed companies, reviewing them in terms of the quality of their reporting. PwC found that companies communicated most effectively about business models, as well as strategy and resource allocation. While the extent of reporting in terms of governance showed the most 
improvement, it still lacked quality. Solomon and Maroun (2012) selected 10 companies listed on the JSE from sectors with a perceived high social and environmental impact. These companies consisted of four mining companies, two construction and materials companies, one petrochemical company, one paper and forestry company, and two companies classified as general industrials. Solomon and Maroun (2012) found that companies managed to shift the viewpoint of the reports within two to three years' time to display a deep understanding of the need for stakeholder accountability and engagement. A striking weakness in the reports was, however, the way in which the companies repeated information, often rephrasing or repeating the same piece of information while certain items of social, environmental and ethical information were excluded (Solomon \& Maroun, 2012; Frías-Aceituno et al., 2013). This indicated that the companies perhaps tried to make the most of a small volume of information or that they did not know how to approach integrated reporting.

Investors and stakeholders rely on integrated reports to be an accurate representation of the social, environmental and ethical activities of an organisation. There is much confusion, clutter and fragmentation in the reporting landscape, resulting in large key disclosure gaps and information provided by some companies being disconnected from actual events (Flower, 2014). As integrated reporting only became mandatory in 2010, it is still a relatively new concept. There are as yet no reports on the long-term effect of mandatory integrated reporting on the level to which social, environmental and ethical information are reported on in the integrated report. Through a detailed review of the content companies report on, more insight can be gained into this question five years after the mandatory implementation of King III.

The research question of this study is how reporting on social, environmental and ethical aspects of integrated reporting have changed over the three-year period from 2012 to 2014. This study uses a similar approach to that of Solomon and Maroun (2012), by reviewing the integrated reports of four companies operating in high social and environmental impact sectors over a period of three years (2012 to 2014), using the same list of social, environmental and ethical items observed by Solomon and Maroun (2012) to ensure consistency between the studies. Since integrated reporting is still in its development phase and not yet implemented everywhere, it is important to do regular 
check-ins to ascertain the progress being made. Using a previous study as a basis ensures that such a review remains consistent, measuring the same items each time a review is conducted.

The results from this study serve as an indication whether integrating reporting still operates as it was intended. The conclusion might also be drawn that, if the level and quality of reporting on these topics in the integrated report has increased, the level of integrated thinking has also increased. As the previous research on this specific topic is somewhat dated, this study will contribute to the current literature and can even open up areas for future research.

This research provides necessary feedback to regulators in terms of the guidelines provided to companies. It also gives stakeholders the opportunity to identify what they find relevant to ensure the reports are useful for decisions and not overly generic. Research can potentially assist managers in the preparation of reports that are useful and include all required information for decision-making, without being unnecessarily repetitive.

The remainder of this paper is structured as follows. In Section 2, we discuss existing literature relating to integrated reporting. In this section, we also provide an interpretation of the evolution of integrated reporting. Section 3 outlines our research method. In Section 4, we present our research findings from a review of the integrated reports of four companies, and the paper concludes with a discussion in Section 5.

\section{LITERATURE REVIEW}

\subsection{The changing landscape for decision making}

For companies to prosper and survive in today's competitive global environment, they need to align their decision making with the interests of society and the environment in which they operate. Organisations such as Nike, Shell and Nestlé have all responded to concerns about the social and environmental impact of their actions (Adams \& Frost, 2008). The increased emphasis on corporate social responsibility in recent years stems mainly from the considerable growth in the number of mutual funds, online resources, 
publications and organisations that specialise in encouraging companies to improve their activities (El Ghoul, Guedhami, Kwok \& Mishra, 2011). Along with an increase in companies' reporting on sustainability issues came an increase in the number of investors using this information for decision making (Serafeim, 2015).

Investors and stakeholders now demand companies to measure and report on nonfinancial information to supplement financial information (Eccles \& Krzus, 2010) as investors are showing an increased tendency to prefer investing in companies that pursue socially responsible activities (El Ghoul et al., 2011). Social Responsible Investment (SRI) investors apply a set of investment screening criteria to select or exclude certain investments based on corporate governance, social and ethical criteria (Renneboog, Ter Horst \& Zhang, 2008). These SRI investors tend to avoid investments in companies that produce hazardous goods or exploit employees, and prefer companies with sound social and environmental records and good corporate governance. Investors and stakeholders want a higher sense of transparency with regard to how companies treat the environment, their community and employees, as well as how they govern themselves (DiPiazza Jr \& Eccles, 2002). Organisations can use transparency in their reporting to gain public trust.

A set of guidelines was developed in 1997 for the preparation of sustainability reports. This set of guidelines is formally known as the Global Reporting Initiative or GRI (Hussey, Kirsop \& Meissen, 2001; Hedberg \& von Malmborg, 2003). Over time the GRI guidelines, and its associated corporate social reports, have become more lengthy and complex. Readers found it difficult to link social, economic and political information across practices and policies, which resulted in information overload and thus the general difficulty in appreciating the interconnections between social, economic and political information was exacerbated (De Villiers et al., 2014).

\subsection{The international integrated reporting council}

The mission of the International Integrated Reporting Council (IIRC) is to bring together social, environmental, financial and governance information in a consistent, clear and comparable way by creating a globally acceptable integrated reporting framework. The aim of the IIRC framework is to guide companies to develop an integrated report that provides more comprehensive information on the total performance of the organisation and to meet 
the needs of a more sustainable, emerging, global economic model (Eccles \& Serafeim, 2011; IIRC, 2013b; Flower, 2014). The IIRC and the Sustainability Accounting Standards Board signed a memorandum to state their support for an emphasis on reduced duplication and the breakdown of internal barriers. Their intent with the memorandum was to bring greater efficiency and cohesion to reporting and accounting processes (IIRC \& SASB, 2013).

Even though the IIRC's vision for its integrated reporting framework has some similarities with the GRI framework, there are substantive differences (De Villiers et al., 2014). The GRI, did not encourage companies or shareholders to consider the value to stakeholders or the organisation. While the reporting of sustainability considerations in performance management and decision making has been slow since the inception of the GRI, according to Adams \& Frost (2008), Adams (2014) is of the opinion that the IIRC is a way to correct this.

Integrated reporting creates a unified objective for the different aspects of an organisation's activities by combining them into one report (KPMG, 2011) and providing stakeholders with information that financial reports fail to provide (Frías-Aceituno et al., 2013). Principles set out by the IIRC to guide the process of integrated reporting are (a) reliability and materiality, (b) future orientation, (c) responsiveness and stakeholder inclusiveness, (d) connectivity of information, and (e) strategic focus (IIRC, 2011). The implementation of integrated reporting shifted the focus from reports being a high-level overview of the organisation to bringing more detail and integration (De Villiers et al., 2014).

\subsection{Reporting frameworks}

The frameworks and standards of non-financial reports such as integrated reports or sustainability reports are not as developed as those for financial reporting. However, there is an increasing demand from shareholders and stakeholders for this type of information (Eccles \& Saltzman, 2011).

Activities such as social and environmental elements are often reported in a framework which combines them. There are three frameworks for this purpose, namely (a) The 
Economics of Ecosystems and Biodiversity, (b) the United Nations Global Impact, and (c) the Global Reporting Initiative. Despite the immense contribution these frameworks make, they only focus on one or two aspects of an organisation's reporting. The IIRC framework, however, combines aspects such as governance and environmental, social, intellectual and financial capital into one report (Abeysekera, 2013) and also allows companies to identify and address any material issues that affect their ability to sustain and create value for the organisation (Eccles \& Serafeim, 2011; EY, 2014).

Individuals searching for a standardised reporting framework will be disappointed by the requirements set out in the IIRC framework. The IIRC framework balances the need for flexibility to recognise the wide variety of circumstances faced by individual companies. It does not expect companies to report on specific key performance indicators, apply certain methods or comply with individual disclosures. The users of integrated reporting should, however, keep in mind that the purpose of an integrated report is to tell a story of the organisation. Without integrated thinking the integrated report is superficial and adds little value to the user (EY, 2014). Integrated thinking is defined as the active consideration of the relationships between the various functional and operational units and the six types of capital the organisation uses (IIRC, 2013a). It is believed the reporting of non-financial information should become a mandatory requirement by all companies worldwide (Eccles \& Serafeim, 2011).

\subsection{The exclusion of key non-financial information by companies}

A common dilemma faced by companies is how much information they should disclose in their annual integrated report. Stakeholders prefer full disclosure, but this is not always possible or advisable. Organisations are thus required to provide balanced information that eliminates the possibility of poor decisions by the users thereof (Kiyanga, 2014). Another important consideration is the fact that the costs of reporting may outweigh the benefits (Belkaoui, 2004), which include losses resulting from the cost of disclosing key information to competitors (Ho \& Wong, 2001).

With the guidelines provided by King III and the integrated reporting framework, there are still numerous companies that fail to report on key non-financial performance issues (Raemaekers, Maroun \& Padia, 2015). A limited perspective is provided by integrated 
reports regarding the implications of current opportunities and risks to the future performance of the organisation. Organisations need to provide more information regarding the position, trends, market conditions and the implications thereof on management plans.

Solomon and Maroun (2012) found the implementation of King III succeeded in increasing the disclosure of social, environmental and ethical issues throughout the various annual reports they scrutinised. Important social, environmental and ethical issues were not only limited to sections such as the "sustainability review" but were also included into core sections such as the "operating review".

In terms of the 10 companies with a high social and environmental impact which Solomon and Maroun (2012) reviewed, the percentage of social items throughout the reports were found to have increased by between $35 \%$ and $87 \%$. The percentage increase for environmental items for the 10 companies ranged between $19 \%$ and $100 \%$. The percentage increase in ethical issues, however, was far less substantial than social and environmental issues, with some companies reporting a $0 \%$ increase in the volume of ethical information.

The implementation of King III and the resulting integrated report brought about a more stakeholder-oriented approach towards reporting. For example, when considering the 'chairman's statement' within the annual reports of Impala Platinum between the 2009 and 2011 financial period, two changes can be seen. In the 2009 report the chairman's statement begins with:

Dear Shareholder, the past year has been hugely challenging and most disappointing, both from a safety performance point of view and in terms of our operating results. Notwithstanding our considerable efforts and initiatives on the safety front, Implats has been unable to drive home a safety culture in a manner that will set it on course to achieve its objective of zero harm by 2012 .

(Impala-Platinum-Holdings-Limited, 2009). 
By 2011, the change in the chairman's statement is notable:

Dear Stakeholder, This year we present to you our second integrated report, which provides an overview of financial indicators and includes our material strategic nonfinancial performance indicators in each area of our reporting, thereby providing an holistic view of our performance for the year. The improved level of transparency enables our shareholders and other stakeholders to fairly evaluate the year under review as well as the future strategic risks and opportunities that are inherent in the Group.

(Impala-Platinum-Holdings-Limited, 2011).

Solomon and Maroun (2012) further found there was a high incidence of repetition and excessive detail towards social, environmental and ethical issues in addition to the increase in the reporting of these aspects. This could arguably be the greatest disadvantage of integrated reports at present.

\section{RESEARCH DESIGN AND METHOD}

Given the questions addressed in this study, the researchers used an interpretive case study approach informed by a thematic content analysis as the primary vehicle for collecting, evaluating and reviewing the data (Mouton, 2001; Beattie, McInnes \& Fearnley, 2004; Babbie, 2007). Integrated reports of a selection of companies were evaluated to establish whether the extent of reporting on social, environmental and ethical aspects in the integrated reports of the selected companies changed significantly in the three-year period from 2012 to 2014, in comparison to the results of the study by Solomon and Maroun (2012), which focused on the prior three-year period from 2009 to 2011

\subsection{Sampling and data collection}

Integrated reports of four companies listed on the JSE were reviewed to evaluate how the companies' integrated reports changed over time. See Table 1 for a summary of the companies reviewed and their industry classification. 
Table 1: Reports used in the analysis

\begin{tabular}{|c|c|}
\hline Company & Industry \\
\hline Impala Platinum (Implats) & Mining \\
\hline Group Five & Construction and materials \\
\hline Sasol & Oil and gas \\
\hline Bidvest & General industrials \\
\hline
\end{tabular}

The four companies from different sectors are considered to be high-impact in terms of social and environmental issues. Their reports should provide a general indication of the extent to which social, environmental and ethical issues are reported on as required by King III. All four companies fall within the top 100 companies on the JSE according to market capitalisation. A small sample was used for a first review of the status of integrated reporting in South Africa.

The annual integrated reports of the selected companies was obtained from their respective websites. These reports are secondary data and since the reports can be considered complete, there was no need to obtain any additional information.

\subsection{Data analysis}

Each company's annual integrated report was reviewed to find the presence of those social, environmental and ethical aspects companies are required to report on according to King III. The exact list of items as was used by Solomon and Maroun (2012) was applied in this study to identify whether companies increased the level of reporting of social, environmental and ethical issues in their integrated reports after the 2011 financial period. Using the same list ensures consistency in any interpretation and/or comparison of the results from the two studies.

The reports were scrutinised to establish the number of times the companies reported a specific item throughout the integrated report. The list of items reviewed is available as an appendix to the manuscript. The results of the review were tabulated next to the relevant King III items companies need to report on. This assisted in easy identification of an increase, decrease or no change in the level of reporting on social, environmental and ethical aspects over the three-year period. 
Specific measures were used to indicate the extent to which companies reported on social, environmental and ethical information throughout the integrated report. The first measure is the "cumulative change over time (CCOT)". The CCOT refers to the change that was observed in every year, added for the three years under review. The CCOT specifically measures the cumulative change (increase or decrease) in the number of sections where the list of social, environmental and ethical items were reported over the three-year period. The CCOT may appear simple in its execution, but it provides an appropriate proxy for the extent to which social, environmental and ethical information are included in the annual report. The "percentage positive change in number of sections" measures the percentage of items in the social, environmental and ethical sections that are reported on to an increased degree over the three years. The "percentage positive or no change in the number of sections" measures the percentage of items within the social, environmental and ethical sections that reflect an increase or no change in the number of sections in which they are reported over the three years and are incremental to the previous measure, as it includes the positive change. The difference between the two values provide the areas where no change was observed in the number of sections over the three-year period.

Unfortunately there are few studies that report on the particular itemised development of integrated reporting. However, as this is an expansion of the study by Solomon and Maroun (2012) the researchers thought it appropriate to do most of the comparison and discussion of results against their findings, since the studies are comparable.

\section{RESULTS}

To obtain a holistic view of the level of reporting of social, environmental and ethical information overall findings are presented in Table 2. Individual item-by-item observations for each company, according to the list at the end of the manuscript, are available upon request from the corresponding author.

Table 2 summarises the CCOT scores for each of the respective companies and shows there was an overall reduction in the extent to which social, environmental and ethical issues are reported on in the annual integrated reports of the four companies as compared to the study by Solomon and Maroun (2012), whose results are also indicated in the table. 
Table 2: Measuring the degree of integration

\begin{tabular}{|c|c|c|c|c|c|c|c|}
\hline & & \multirow[b]{2}{*}{ Implats } & \multirow[b]{2}{*}{$\begin{array}{l}\text { Group } \\
\text { Five }\end{array}$} & \multirow[b]{2}{*}{ Sasol } & \multirow[b]{2}{*}{ Bidvest } & \multicolumn{2}{|c|}{ Total range } \\
\hline & & & & & & $\begin{array}{l}2009 \text { to } 2011 \\
\text { (Solomon and } \\
\text { Maroun, 2012) }\end{array}$ & 2012 to 2014 \\
\hline \multirow[t]{3}{*}{ Social } & Total CCOT & +5 & -15 & -51 & -37 & +194 & -98 \\
\hline & $\begin{array}{l}\% \text { Positive change in } \\
\text { number of sections }\end{array}$ & $31 \%$ & $35 \%$ & $3 \%$ & $5 \%$ & $60 \%-87 \%$ & $3 \%-35 \%$ \\
\hline & $\begin{array}{l}\% \text { Positive or no change in } \\
\text { number of sections }\end{array}$ & $59 \%$ & $55 \%$ & $32 \%$ & $14 \%$ & $90 \%-97 \%$ & $14 \%-59 \%$ \\
\hline \multirow[t]{3}{*}{ Environmental } & Total CCOT & -5 & -8 & -31 & -14 & +71 & -58 \\
\hline & $\begin{array}{l}\% \text { Positive change in } \\
\text { number of sections }\end{array}$ & $22 \%$ & $18 \%$ & $0 \%$ & $0 \%$ & $55 \%-100 \%$ & $0 \%-22 \%$ \\
\hline & $\begin{array}{l}\% \text { Positive or no change in } \\
\text { number of sections }\end{array}$ & $50 \%$ & $27 \%$ & $0 \%$ & $20 \%$ & $64 \%-100 \%$ & $0 \%-50 \%$ \\
\hline \multirow[t]{3}{*}{ Ethical } & Total CCOT & -3 & -1 & -1 & -6 & +8 & -11 \\
\hline & $\begin{array}{l}\% \text { Positive change in } \\
\text { number of sections }\end{array}$ & $0 \%$ & $43 \%$ & $40 \%$ & $0 \%$ & $29 \%-80 \%$ & $0 \%-43 \%$ \\
\hline & $\begin{array}{l}\% \text { Positive or no change in } \\
\text { number of sections }\end{array}$ & $40 \%$ & $57 \%$ & $60 \%$ & $25 \%$ & $43 \%-100 \%$ & $25 \%-60 \%$ \\
\hline
\end{tabular}


There was thus a perceived reduction in the availability of social, environmental and ethical information within integrated reports since 2011. This can be the result of poor integrated reporting, as found by Raemaekers et al. (2015), or a reduction in repetition, an aspect which was found by Solomon and Maroun (2012), as well as Frías-Aceituno et al. (2013) to be a problem of integrated reporting.

Table 2 further indicates that the positive percentage increase of social items for the four companies ranged between $3 \%$ and $35 \%$. As the integrated reports of companies develop, they not only tend to reduce the number of pages in their reports (refer to Table 3), but also the volume of social information. This is consistent with the findings of Solomon and Maroun (2012), who found companies tend to reduce their reporting of specific issues to specific sections as was the case prior to the introduction of King III and integrated reporting. The results give the impression that the four companies have changed their approach towards integrated reporting since 2012. This can be a positive sign, indicating that the problems of disconnect and gaps in integrated reports, as reported by Flower (2014), may be on the decrease as the quality of integrated reports improve.

Table 3: Change in the number of pages over the 2011 to 2014 period

\begin{tabular}{|c|c|c|c|}
\hline & $\begin{array}{c}\text { Number of pages } \\
(\mathbf{2 0 1 1 )}\end{array}$ & $\begin{array}{c}\text { Number of pages } \\
(\mathbf{2 0 1 4})\end{array}$ & $\begin{array}{c}\text { Change in the } \\
\text { number of pages }\end{array}$ \\
\hline Implats & 220 & 154 & -66 \\
\hline Group Five & 260 & 178 & -82 \\
\hline Sasol & 148 & 124 & -24 \\
\hline Bidvest & 230 & 162 & -68 \\
\hline
\end{tabular}

Table 2 indicates that the percentage increase for environmental items over the three-year period was less than that of social items. The positive percentage increase for environmental items ranged between $0 \%$ and $22 \%$. This was again substantially less than the $19 \%$ to $100 \%$ increase in the number of sections where environmental items were reported over the 2009 to 2011 financial years, as found by Solomon and Maroun (2012). As three of these companies (i.e. Impala Platinum, Sasol and Group Five) are considered to be high environmental impact companies, this figure is remarkable. These high environmental impact companies have a responsibility towards shareholders and stakeholders to provide high quality reports that provide interested parties with important information about environmental issues. 
The number of sections where there was an increase in the number of ethical issues reported on range between $0 \%$ and $44 \%$. This was more than that of both social and environmental issues combined, which is in contrast to the study by Solomon and Maroun (2012), who found the implementation of integrated reports lead companies to report more extensively on social and environmental issues as compared to ethical issues.

The sections in which there were a positive or no percentage increase was between $14 \%$ and $59 \%$ for social items, between $0 \%$ and $50 \%$ for environmental items, and between $25 \%$ and $60 \%$ for ethical items. This indicates that the companies, in some cases, did not improve at all on the number of sections in which they reported on social, environmental and ethical issues. While the implementation of integrated reports did help to increase the exposure of the above-mentioned items, there was unfortunately little continuous improvement on these aspects afterwards.

Solomon and Maroun (2012) and Frías-Aceituno et al. (2013) found certain items of social, environmental and ethical information were often repeated excessively throughout integrated reports. The results in Table 2 suggest companies reduced the excessive repetition of information over the subsequent three years following 2011. Organisations had more information to provide in relatively fewer pages as can be seen in Table 3.

As an example, observe the differences between the 2011 and 2014 annual integrated report of Group Five in Table 4. The table gives an indication of the change in orientation in the integrated report over the three-year period.

Group Five had fewer sections in the 2014 integrated report compared to 2011. It also appears that Group Five left out important sections in its 2014 integrated report, such as the review from the CEO and the chief financial officer (CFO), the operational overview from the CFO, and the King III summary. A change in section titles further suggests a possible change in the strategy of the organisation. The 2011 integrated report contained an individual report from each director in the organisation and therefore covered all aspects, including social and environmental. Group Five excluded these sections from their 2014 integrated report, which raises some questions since these sections highlight and increase clarity around important issues. 
Table 4: Sections within the 2011 and 2014 integrated reports

\begin{tabular}{|c|c|c|c|}
\hline \multicolumn{2}{|r|}{2011 annual integrated report } & \multicolumn{2}{|r|}{2014 annual integrated report } \\
\hline Page & Section & Page & Section \\
\hline \multicolumn{2}{|c|}{ Introduction to the group } & \multicolumn{2}{|c|}{ Contents } \\
\hline 004 & Report approach & 2 & About this report \\
\hline 006 & Unpacking our material issues & 4 & History of Group Five \\
\hline 010 & Group structure & 10 & Our strategy and structure \\
\hline 012 & Geographic footprint & 18 & How our stakeholder impact our strategy \\
\hline 014 & Delivery on group strategy & \multicolumn{2}{|c|}{ Year under review } \\
\hline 020 & Sector focus & 26 & $\begin{array}{l}\text { How our strategy assisted us to deliver against } \\
\text { our material issues }\end{array}$ \\
\hline 034 & The board & 60 & Financial and operational performance \\
\hline 036 & Team performance & \multicolumn{2}{|c|}{ How we are governed, measured and remunerated } \\
\hline \multicolumn{2}{|c|}{ Delivery during the year } & 90 & Combined assurance \\
\hline 044 & Delivery against group measures & 97 & Our group measures \\
\hline 046 & Ten-year review & 102 & Or team's measures \\
\hline 048 & Key ratios & 123 & Our team's remuneration \\
\hline 050 & Assurance processes & \multicolumn{2}{|c|}{ Summary consolidated annual financial statements } \\
\hline 053 & Scorecards & 152 & Directors' responsibility statement \\
\hline 060 & Awards & 153 & Report of the independent auditor \\
\hline \multicolumn{2}{|c|}{ Messages from the team } & 154 & $\begin{array}{l}\text { Summary consolidated annual financial } \\
\text { statements }\end{array}$ \\
\hline 064 & Review from the chairperson & 155 & Group income statement \\
\hline 067 & $\begin{array}{l}\text { Review from the chairperson of the } \\
\text { audit and }\end{array}$ & 156 & Group statement of comprehensive income \\
\hline 070 & Remuneration report & 156 & Determination of group headline earnings \\
\hline 077 & $\begin{array}{l}\text { Review from the chairperson of the } \\
\text { risk committee }\end{array}$ & 157 & Group statement of financial position \\
\hline 079 & $\begin{array}{l}\text { Review from the chairperson of the } \\
\text { SED committee }\end{array}$ & 158 & Group statement of cash flow \\
\hline 081 & Review from the CEO & 158 & Group capital expenditure and depreciation \\
\hline 086 & Review from the CFO & 159 & Group statement of changes in equity \\
\hline 090 & Operational overview from the CFO & 161 & Group segmental analysis \\
\hline 094 & Executive committee & 164 & Group statistics \\
\hline 096 & Management committee & 164 & Estimates and contingencies \\
\hline 101 & Review from the group risk officer & 165 & Dividend declaration \\
\hline 104 & $\begin{array}{l}\text { Operational overview from the group } \\
\text { risk officer }\end{array}$ & 166 & Analysis of shareholders \\
\hline 115 & Review from the company secretary & 169 & Notice of the annual general meeting \\
\hline 119 & King III summary & 175 & Form of proxy \\
\hline 125 & $\begin{array}{l}\text { Review from the group human } \\
\text { resources director }\end{array}$ & & \\
\hline 128 & $\begin{array}{l}\text { Operational overview from the group } \\
\text { human resources director }\end{array}$ & & \\
\hline
\end{tabular}




\begin{tabular}{|c|l|l|l|}
\hline 141 & Operational reviews & & \\
\hline 141 & Group structure & & \\
\hline 142 & Investments and Concessions & & \\
\hline 143 & Infrastructure Concessions & & \\
\hline 148 & Property Developments & & \\
\hline 151 & Manufacturing & & \\
\hline 156 & 156 Construction Materials & & \\
\hline 160 & 160 Construction & & \\
\hline 161 & Building and Housing & & \\
\hline 166 & Civil Engineering & & \\
\hline 171 & Engineering & & \\
\hline Annual financial statements & & \\
\hline 178 & Annual financial statements & & \\
\hline 256 & Notice of the AGM & & \\
\hline 259 & Form of proxy & \\
\hline
\end{tabular}

\subsection{Impala Platinum (Implats)}

Table 5 provides a summary of the number of sections as well as the change in the number of sections within which social, environmental and ethical issues are reported in the 2012, 2013 and 2014 integrated reports of Implats.

Table 5: Impala Platinum: The degree of integration of social, environmental and ethical issues

\begin{tabular}{|l|l|c|c|c|}
\hline $\begin{array}{l}\text { Impala } \\
\text { Platinum }\end{array}$ & Total CCOT & $\mathbf{+ 5}$ & $\mathbf{- 5}$ & -3 \\
\hline & $\begin{array}{l}\text { Percentage positive change in } \\
\text { number of sections }\end{array}$ & $31 \%$ & $22 \%$ & $0 \%$ \\
\hline & $\begin{array}{l}\text { Percentage positive or no change in } \\
\text { number of sections }\end{array}$ & $59 \%$ & $50 \%$ & $40 \%$ \\
\hline
\end{tabular}

In the individual item-by-item review, an overall increase in the number of sections where social issues appear throughout the integrated report was found. However, there was an overall reduction in the number of sections where safety issues were reported. The only safety issues for which there has been increased exposure are safety training and the total injury frequency rate. Other safety issues such as the safety levels, safety audits, zero harm, and number of fatalities all showed reduced disclosure. 
Implats decreased the level of reporting on medical-related information, such as HIV/AIDS cases, throughout the integrated report. During 2011, HIV/AIDS related aspects were discussed and mentioned in key sections such as the chairman's statement, the CEO's statement, the performance statement and the operational review. An estimated $25 \%$ to $30 \%$ of the South African mining workforce has HIV/AIDS. The mining industry is a highly competitive labour-intensive industry that requires employees to be mentally alert and fit to maintain safety levels and productivity (Solomon \& Maroun, 2012). It is therefore important for companies such as Implats to report this type of information in their integrated report as it may impact their operations and the decision making of investors and stakeholders.

The individual item-by-item review indicates that there was an overall increase in the number of sections where education- and skills related-aspects were reported. Implats thus placed much emphasis on the development of employees. There was a further increase in the exposure of transformation, historically disadvantaged South African citizens' ownership and empowerment, and local procurement aspects. This phenomenon is not surprising given the historic significance of social issues, especially transformation and black economic empowerment following the end of apartheid. Another area where Implats improved considerably with regard to its reporting relates to indigenisation quotas. For example, Implats is largely affected by its indigenisation plans within Zimbabwe and the organisation is under pressure to meet targets as set out by the government of Zimbabwe.

A decrease was observed in the number of sections in the 2014 integrated report where environmental issues were reported. Implats recognised the need to comply with environmental regulations in its 2011 integrated report and identified a number of issues as important to the sustainability of the organisation. Firstly, there is the need to comply with environmental legislation from a regulatory perspective. Secondly, Implats needs to manage its resources effectively as well as maintain ISO 140001 approved environmental management systems. Finally, Implats have to develop a strategy to control and reduce its carbon emissions to achieve certain targets (Solomon \& Maroun, 2012). In its 2014 integrated report, Implats acknowledged the implementation of its carbon strategy and that its focus needs to remain on energy efficient projects. Implats' 2014 integrated report again mentioned the challenges and the need to comply with environmental legislation. 
However, the need to maintain ISO 1400001 environmental management systems was not mentioned (Impala-Platinum-Holdings-Limited, 2014).

In terms of the disclosure of ethical issues, Implats reduced the number of sections in which it reported this type of information. Issues regarding integrity, accountability and responsibility received less attention in the 2014 integrated report as compared to the 2011 integrated report.

\subsection{Group Five}

Table 6 provides a summary of the number of sections where social, environmental and ethical issues were reported within the integrated reports of Group Five for the three-year period, 2012 to 2014.

Table 6: Group Five: The degree of integration of social, environmental and ethical issues

\begin{tabular}{|l|l|c|c|c|}
\hline $\begin{array}{l}\text { Group } \\
\text { Five }\end{array}$ & Total CCOT & -15 & -8 & -1 \\
\hline & $\begin{array}{l}\text { Percentage positive change in number } \\
\text { of sections }\end{array}$ & $35 \%$ & $18 \%$ & $43 \%$ \\
\hline & $\begin{array}{l}\text { Percentage positive or no change in } \\
\text { number of sections }\end{array}$ & $55 \%$ & $27 \%$ & $57 \%$ \\
\hline
\end{tabular}

There was a considerable reduction in the number of sections in which social issues were reported within the 2014 integrated report of Group Five. The CCOT of -19 is largely due to the reduction in the disclosure on the following items: safety performance, disabling injury frequency rate, HIV/AIDS, occupational health programmes, employee training, and socio-economic development programmes. With regard to safety information, Group Five reduced the amount of reporting of safety performance to two sections compared to six in 2011. This may be the result of better reporting techniques and a conscious reduction of repetition. Group Five further decided to exclude information about the disabling injury frequency rate and provide more information about the lost time injury frequency rates

As was the case with Implats, Group Five reduced the disclosure of health issues in its 2014 integrated report. They excluded information about diseases such as HIV/AIDS, tuberculosis and malaria. Group Five also reduced the amount of reporting of information 
regarding occupational health programmes. During 2011 Group Five launched an HIV/AIDS programme to support employees with HIV/AIDS as can be seen in its 2011 integrated report:

The group also launched an employee assistance programme to support the group's HIV/Aids programme. These programmes were both funded as social spend under the SED programme in line with the DTI Code of Good Practice and the Construction Charter.

(Group-Five, 2011)

However, this was where this type of reporting stopped, as Group Five did not provide further feedback about its HIV/AIDS programme, tuberculosis or malaria situation in its 2012, 2013 and 2014 integrated reports.

There was also a reduction in the number of sections where BEE issues and matters pertaining to socio-economic development programmes were reported. Group Five further reduced the number of sections in which it reported aspects with regard to the activities of the board. These findings support those of PwC (2014), which indicated 59\% of the top 40 companies on the JSE neglected to report on the activities of the board. These companies did not report on the board diversity, gender equality or the responsibilities of women on the board.

Group Five had fewer issues to report on in terms of environmental aspects than, for example Implats and Sasol, which are located in high environmental impact sectors. Group Five reduced the disclosure of environmental items in its 2014 integrated report. The reporting of issues such as environmental compliance and environmental rehabilitation was missing from all reports. In terms of ethical issues, Group Five experienced a CCOT of -1 as observed in Table 6 . It also increased reporting on issues such as integrity, accountability and ethical standards. 


\subsection{Sasol}

Table 7 provides a summary of the number of sections, as well as the change in the number of sections within which social, environmental and ethical issues were reported within the integrated reports of Sasol over the three-year period, 2012 to 2014.

Table 7: Sasol: The degree of integration of social, environmental and ethical issues

\begin{tabular}{|l|l|c|c|c|}
\hline Sasol & Total CCOT & -51 & -31 & -1 \\
\hline & $\begin{array}{l}\text { Percentage positive change in number } \\
\text { of sections }\end{array}$ & $3 \%$ & $0 \%$ & $40 \%$ \\
\hline & $\begin{array}{l}\text { Percentage positive or no change in } \\
\text { number of sections }\end{array}$ & $32 \%$ & $0 \%$ & $60 \%$ \\
\hline
\end{tabular}

The introduction of the integrated report in 2011 resulted in an increased social CCOT of +89 from the 2009 financial period. Sasol focused much attention on aspects such as governance for sustainability, health and safety audits, the transformation process and engagement with stakeholders. The introduction of the integrated report had the desired effect in terms of increasing the exposure of social items throughout the report (Solomon \& Maroun, 2012). It was found the social CCOT of Sasol decreased by -51 over the subsequent three-year period after the introduction of integrated reporting in 2011. Aspects such as governance for sustainability, health and safety audits, the transformation process, equity participation levels, and return to stakeholders - which previously experienced an increase in 2011 - experienced a considerable decrease in the 2014 integrated report. Sasol also did not focus as much on issues such as BEE ownership and local procurement. In addition, Sasol did not provide disclosure about stakeholder-related issues such as stakeholder engagement, general stakeholder aspects and return to stakeholders.

As with social reporting, Sasol reduced the number of sections in which it reported on environmental aspects. Sasol's CCOT of -31 in 2014 was almost the exact opposite of their CCOT of +30 during 2011. This is remarkable given the fact that Sasol is a high environmental-impact organisation and has a responsibility towards stakeholders to deliver high-quality reporting in terms of environmental aspects. In addition, Sasol did not report on environmental items such as carbon emissions, climate change, renewable energy and 
waste management. Sasol mentioned in its 2014 integrated report it want to move away from coal to gas energy, and to promote its gas to power energy initiatives to reduce their impact on the environment (Sasol, 2014). Even though this (relatively big) decision affect different aspects of the company and one would think to see it mentioned throughout a report, it is only mentioned once throughout the entire 2014 integrated report.

Sasol was ranked fifth in Ernest and Young's "Excellence in integrated reporting 2013" awards. However, Sasol neglected to report on concerns about a so-called "carbon bubble", which might result in companies not being able to extract coal in the future. This raises questions about the credibility of Sasol's integrated report (Adams, 2014). Organisations should be transparent regarding their philosophies, as well as the extent to which they add value to all stakeholders, and not only their shareholders (Rensburg \& Botha, 2014).

Sasol's reporting on ethical issues in its 2014 integrated report was higher than its social and environmental aspects. The organisation also increased the disclosure of accountability and ethical standards. The chairman of Sasol emphasises the importance of being accountable towards stakeholders in building long-term relationships.

\subsection{Bidvest}

Table 8 provides a summary of the number of sections as well as the change in the number of sections within which social, environmental and ethical issues are reported within the integrated reports of Bidvest over the three-year period, 2012 to 2014.

Table 8: Bidvest: The degree of integration of social, environmental and ethical issues

\begin{tabular}{|l|l|c|c|c|}
\hline Bidvest & Total CCOT & -37 & -14 & -6 \\
\hline & $\begin{array}{l}\text { Percentage positive change in } \\
\text { number of sections }\end{array}$ & $5 \%$ & $0 \%$ & $0 \%$ \\
\hline & $\begin{array}{l}\text { Percentage positive or no change in } \\
\text { number of sections }\end{array}$ & $14 \%$ & $20 \%$ & $25 \%$ \\
\hline
\end{tabular}

As was the case with Implats and Sasol, Bidvest reduced the number of sections in which social items were reported. The CCOT over the 2009 to 2011 period was +38 for Bidvest, 
while the subsequent three years (2012 to 2014) showed an almost exact opposite CCOT of -37. The major contributing sections where reporting decreased were safety levels, HIV/AIDS, BEE and stakeholder engagement aspects. Bidvest employs 143828 people worldwide (Bidvest, 2014) and has therefore a high social impact with the responsibility for the well-being of thousands of employees, as well as other stakeholders. Despite Bidvest being one of the largest companies in South Africa, it did not report on social aspects such HIV/AIDS, strikes, bursary programmes, and transformation processes within the organisation. Employees and customers form an intricate part of the company's activities. It is therefore important for Bidvest to report on social issues to their investors and stakeholders.

In its 2014 integrated report Bidvest states in their "value creation section" that:

As an employer of 143828 people, Bidvest's annual integrated report contains information on a number of people-based sustainability indicators. The resources used within the Bidvest environment centre around our human capital; our people with their competencies, experience and expertise.

(Bidvest, 2014)

This information, however, is not presented throughout the report. Bidvest further reduced the number of sections in which environmental items were mentioned. Aspects such as its carbon footprint, renewable energy and water management experienced the largest declines. During 2011 Bidvest performed its fifth greenhouse gas emissions inventory (carbon footprint), on all its businesses. This gave a thorough perspective on their position with regard to their impact on the environment (Bidvest, 2011). Bidvest did not report on their carbon footprint activities in its 2014 integrated report. Bidvest needs to consider the signalling effects of their activities. Furthermore, Bidvest reduced the number of sections in which it mentioned ethical issues. There was a considerable reduction in the number of sections in which integrity-related issues and ethical standards were discussed.

\section{CONCLUSIONS AND AREAS FOR FURTHER RESEARCH}

The paper provides evidence that integrated reporting is still in its development phase and that it will take some time before all companies are fully on board and understand the need 
and purpose for integrated reporting. The review of the integrated reports of four companies painted a complex picture of the impact the introduction of King III has had on the reporting of social, environmental and ethical issues and the results deliver both positive and negative findings.

In the Solomon and Maroun (2012) study it was clear that the implementation of King III initially mainly led to increased disclosure of social, environmental and ethical issues throughout the integrated report as a whole. These three aspects collectively appear in a greater number of sections in the 2011 integrated reports compared to the 2009 annual financial reports. The findings of this study, however, indicate there was a reduction in the amount of reporting during the subsequent three-year period after the introduction of integrated reports by companies in 2011. There are multiple possible reasons for this. From a positive viewpoint it may signal that companies are taking steps to reduce the excessive length of their integrated reports and took heed of complaints about repetition, are making a bigger effort to integrate sections, and are perhaps also categorising the topics of the report better. From a negative viewpoint, one may get the impression that it became too onerous for companies to report on all aspects required by integrating reporting guidelines and decided to focus on presenting the bare minimum.

The study by Solomon and Maroun (2012) indicated that information was often repeated excessively throughout the 2011 integrated reports. Within a three-year period, along with the increased information needs of stakeholders, these companies have eliminated this tendency to repeat information. This tendency is also evident in the reduction in the total number of pages of the integrated reports in the subsequent years.

Considering that investors and stakeholders use information to make investment and other decisions, companies have to be cognisant of the message they send out to stakeholders. Despite the improvement in the integrated reports of the four companies with regard to the repetition of information, this research has shown a reduction in the overall value of these respective reports as a result of the exclusion of various important pieces of information that were provided in the 2011 integrated reports and not followed up on in the 2014 integrated reports. These pieces of information are pivotal for decision making by investors and stakeholders. For example, Group Five did not provide further feedback in its 2014 integrated report in terms of its HIV/AIDS programme, tuberculosis or malaria situation, 
which they reported on extensively in its 2011 integrated report. Sasol also eliminated key sections that provided useful information to stakeholders in 2011.

Implats is the only organisation with a positive value for the CCOT in terms of social issues. Despite this achievement it failed to report on ethical aspects. Implats may have to provide more assurance to its investors and stakeholders that it can be held accountable for its activities and will act in a responsible and ethical manner. Group Five did not perform well in terms of the quality of its 2014 integrated report. Moreover, Group Five did not report on the social or environmental issues it had identified and reported on in its 2011 integrated report. This was largely attributable to the elimination of key sections such as the review from the CEO and the CFO, amongst others. The elimination of these sections removed valuable information that could have been used by investors and stakeholders.

Even though the findings of this study can be the result of a number of factors, it provides additional evidence of the findings by PwC (2013), who found that companies struggle to improve on the quality of their integrated reports from previous financial periods. In some cases it appears as if companies reduced their efforts to enhance and improve their integrated reports over the subsequent three-year period after the Solomon and Maroun (2012) study period. Regulators may have to provide more detailed guidelines about the reporting requirements of companies, while companies need to re-align their focus towards the basics of integrated reporting and develop a mind-set to continuously improve their reporting. This is necessary to create the most value and to assist investors and stakeholders in decision making.

The results from this study suggest that the manner to improve the quality of integrated reports may be hidden in the type of sections and the information disclosed within reports, as well as proper integration of sections. Managers should take heed that a reduction in the number of times certain social, environmental and ethical issues are repeated in an integrated report does not necessarily enhance the quality. A way to improve the quality of integrated reports is to integrate social, environmental and ethical issues in other relevant sections of the report to ensure an equal spread of information throughout. It is evident from the results of this study that certain types of information are restricted to certain sections within the report. 
The study has some limitations. The size of the sample prevent the possibility of generalising to other companies and industries. Further research could address this apparent gap in generalisability. It is also important to identify the main issues JSE-listed companies neglect to report on in terms of the eight content elements set out in the integrated reporting framework. This may help other companies in similar situations overcome their challenges and comply with all the necessary requirements of King III. One need to consider that there are possibly a large variety of reasons why certain items are reported on to an increased or decreased extent from one period to the next.

Other potential areas for study are the exact reasons why certain items are reported on to a greater or a lesser extent from one year to the next, and how the quality of integrated reports can be improved by increasing engagement with stakeholders. Stakeholders can be requested to give feedback with regard to the type of information they require from an integrated report. Organisations can even go so far as to include a section in which they publish the feedback from various influential stakeholders. This will result in other stakeholders joining the conversation about what should ideally be included in an integrated report.

\section{REFERENCES}

Abeysekera, I. (2013), "A template for integrated reporting", Journal of Intellectual Capital, Vol. 14 No. 2, pp. 227-245.

Adams, C.A. \& Frost, G.R. (2008), "Integrating sustainability reporting into management practices", Accounting Forum, Vol. 32 No. 1, pp. 288-302.

Adams, C.A. (2014), "The International Integrated Reporting Council: A call to action", Critical Perspectives on Accounting, Vol. 27 No. 1, pp. 23-28.

Atkins, J. F., Solomon, A., Norton, S., Joseph, N. L., (2015), "The emergence of integrated private reporting", Meditari Accountancy Research, Vol. 23 No. 1, pp. 28-61.

Atkins, J., Maroun, W., (2015), "Integrated reporting in South Africa in 2012: Perspectives from South African institutional investors", Meditari Accountancy Research, Vol. 23 No. 2, pp. 197-221.

Babbie, E. 2007, The Practice of Social Research, 11th edition, Chapman Publishers, London. 
Beattie, V., Mclnnes, B. \& Fearnley, S. (2004), "A methodology for analysing and evaluating narratives in annual reports: a comprehensive descriptive profile and metrics for disclosure quality attributes", Accounting Forum, Vol. 28 No. 3, pp. 205-236.

Belkaoui, R.A. 2004. Accounting Theory, 5th edition, Thomson Learning, London.

Bidvest. (2011), "Bidvest annual integrated report 2011", available at: http://www.bidvest.co.za/ar/bidvest_ar2011/index.php (accessed 25 August 2015).

Bidvest. (2014). "Bidvest annual integrated report 2014", available at: http://www.bidvest.co.za/ar/bidvest_ar2014/index.php (accessed 25 August 2015).

De Villiers, C., Rinaldi, L. \& Unerman, J. (2014), "Integrated Reporting: Insights, gaps and an agenda for future research", Accounting, Auditing \& Accountability Journal, Vol. 27 No. 7, pp. 1042-1067.

DiPiazza Jr, S.A. \& Eccles, R.G. (2002), Building public trust: The future of corporate reporting, John Wiley \& Sons, New York (NY).

Eccles, R. \& Armbrester, K. (2011), "Integrated reporting in the cloud", IESE Insight, Vol. 8 No. 1, pp. 13-20.

Eccles, R.G. \& Krzus, M.P. (2010), One report: Integrated reporting for a sustainable strategy, John Wiley \& Sons Inc, New Jersey (NY).

Eccles, R.G. \& Saltzman, D. (2011), "Achieving sustainability through integrated reporting", Stanf Soc Innov Rev Summer, Vol. 1 No. 1, pp. 56-61.

Eccles, R.G. \& Serafeim, G. (2011), "Accelerating the adoption of integrated reporting", InnoVatio Publishing Limited, Vol. 1 No. 1, pp. 1-29.

El Ghoul, S., Guedhami, O., Kwok, C.C. \& Mishra, D.R. (2011), "Does corporate social responsibility affect the cost of capital?", Journal of Banking \& Finance, Vol. 35 No. 9, pp. 2388-2406.

EY. (2014), "EY's Excellence in Integrated Reporting Awards", available at: http://www.ey.com/Publication/vwLUAssets/EY-Excellence-In-Integrated-Reporting2014/\$FILE/EY-Excellence-In-Integrated-Reporting-2014.pdf (accessed 18 May 2015).

Flower, J. (2014), "The international integrated reporting council: a story of failure", Critical Perspectives on Accounting, Vol. 27 No. 1, pp. 23-28.

Frías-Aceituno, J., Rodríguez-Ariza, L. \& García-Sánchez, I. (2013), "Is integrated reporting determined by a country's legal system? An exploratory study", Journal of Cleaner Production, Vol. 44 No. 1, pp. 45-55.

Group-Five. (2011), "Group Five annual integrated report 2011", available at: http://www.g5.co.za/reports/ar_2011/pdf/full.pdf (accessed 24 August 2015). 
Hedberg, C.J. \& von Malmborg, F. (2003), "The Global Reporting Initiative and corporate sustainability reporting in Swedish companies", Corporate social responsibility and environmental management, Vol. 10 No. 3, pp. 153-164.

Ho, S.S. \& Wong, K.S. (2001), "A study of the relationship between corporate governance structures and the extent of voluntary disclosure", Journal of International Accounting, Auditing and Taxation, Vol. 10 No. 2, pp. 139-156.

Hussey, D.M., Kirsop, P.L. \& Meissen, R.E. (2001), "Global reporting initiative guidelines: an evaluation of sustainable development metrics for industry", Environmental Quality Management, Vol. 11 No. 1, pp. 1-20.

Ighian, D.S.C. (2015), "Integrated Reporting-The Future Of Financial Reporting", Internal Auditing and Risk Management, Vol. 38 No. 1, pp. 125-134.

Impala-Platinum-Holdings-Limited (2009), "Annual Report 2009", available at: http://www.implats.co.za/reports/2009/ar/f/implats_ar09.pdf (accessed 17 August 2015).

Impala-Platinum-Holdings-Limited. (2011), "Implats Integrated Annual Report 2011", available at: http://www.implats.co.za/implats/downloads/2011/annual\%20reports/lmplats \%20AR_Combined_LoRes.pdf (accessed 17 August 2015).

Impala-Platinum-Holdings-Limited. (2014), "Implats Integrated Annual Report 2014", available at: http://www.implats.co.za/implats/downloads/2014/Implats_integrated_report_ 2014.pdf (accessed 24 August 2015).

International Integrated Reporting Council (IIRC) \& Sustainability Accounting Standards Board (SASB) (2013), "Memorandum of Understanding.1-8", available at: http://integratedreporting.org/wp-content/uploads/2014/01/MoU-IIRC-SASB-Final.pdf (accessed 15 May 2015).

International Integrated Reporting Council (IIRC) (2011), "Towards integrated reporting. Communicating value in the 21 st century", available at: http://hipinvestor.com/wpcontent/uploads/Integrated-Reporting.pdf (accessed 15 May 2015).

International Integrated Reporting Council (IIRC) (2013a), "The international IR framework", available at: www.theiirc.org/international-ir-framework/ (accessed 8 June 2015).

International Integrated Reporting Council (IIRC) (2013b), "Basis for Conclusions. International IR Framework", available at: www.theiirc.org/wp-content/uploads/2013/12/1312-08-Basis-for-conclusions-IR.pdf (accessed 16 August 2015).

Kiyanga, B.P.L. (2014), Corporate disclosure quality-a comparative study of Botswana and South Africa, Unpublished Master's Dissertation, University of South Africa, Pretoria.

KPMG. (2011), "Integrated reporting. Performance insight through better business reporting. Issue 1", available at: https://www.kpmg.com/Global/en/lssuesAndlnsights/Articles Publications/Documents/road-to-integrated-reporting.pdf (accessed 15 May 2015). 
Mouton, J. (2001), How to succeed in your masters \& doctoral studies. A South African guide and resource book, Van Schaik Publishers, Pretoria.

PwC. (2013), "Integrated Reporting Companies struggle to explain what value they create", available at: http://www.pwc.nl/nl_NL/nl/assets/documents/ir-opmarsgeintegreerde-verslaggeving-stagneert.pdf (accessed 17 June 2015).

PwC. (2014), 'Value creation: The journey continues: A survey of JSE Top-40 companies' integrated reports", available at: http://www.pwc.co.za/en_ZA/za/assets/pdf/integratedreporting-survey-2014.pdf (accessed 17 June 2015).

Raemaekers, K., Maroun, W. \& Padia, N. (2015), "Risk disclosures by South African listed companies post-King III", South African Journal of Accounting Research, DOI: 10.1080/10291954.2015.1021583.

Renneboog, L., Ter Horst, J. \& Zhang, C. (2008), "Socially responsible investments: Institutional aspects, performance, and investor behaviour", Journal of Banking \& Finance, Vol. 32 No. 9, pp. 1723-1742.

Rensburg, R. \& Botha, E. (2014), "Is Integrated Reporting the silver bullet of financial communication? A stakeholder perspective from South Africa", Public Relations Review, Vol. 40 No. 2, pp. 144-152.

Sasol. 2014. "Sasol annual integrated report 2014", available at: http://www.sasol.co.za/ investor-centre/publications/integrated-report-1 (accessed 24 August 2015).

Serafeim, G. (2015), "Integrated Reporting and Investor Clientele", Journal of Applied Corporate Finance, Vol. 27 No. 2, pp. 34-51.

Solomon, J. \& Maroun, W. (2012), Integrated reporting: the influence of King III on social, ethical and environmental reporting: ACCA Research Report, The Association of Chartered Certified Accountants, London.

Stent, W., Dowler, T., (2015), "Early assessments of the gap between integrated reporting and current corporate reporting", Meditari Accountancy Research, Vol. 23 No. 1, pp. 92117. 


\section{APPENDIX}

Table 9: List of items that were individually reviewed in each integrated report

\begin{tabular}{|c|c|c|c|c|c|}
\hline ANNUAL IR & 2011 & 2012 & 2013 & 2014 & CCOT \\
\hline \multicolumn{6}{|l|}{ Report length (pages) } \\
\hline \multicolumn{6}{|l|}{ SOCIAL } \\
\hline \multicolumn{6}{|l|}{ Total employment figure } \\
\hline \multicolumn{6}{|l|}{ Employee turnover } \\
\hline \multicolumn{6}{|l|}{$\begin{array}{l}\text { SHE/HSE audit committee } \\
\text { (role/membership) }\end{array}$} \\
\hline \multicolumn{6}{|l|}{$\begin{array}{l}\text { Safety levels (general, performance, } \\
\text { principles, targets) }\end{array}$} \\
\hline \multicolumn{6}{|l|}{ Safety training } \\
\hline \multicolumn{6}{|l|}{$\begin{array}{l}\text { Safety audits/DuPont safety } \\
\text { survey/assessment }\end{array}$} \\
\hline \multicolumn{6}{|l|}{ Zero harm } \\
\hline \multicolumn{6}{|l|}{ Behaviour-based safety initiatives } \\
\hline \multicolumn{6}{|l|}{ Fatalities } \\
\hline \multicolumn{6}{|l|}{ Fatal injury frequency rate (FIFR) } \\
\hline \multicolumn{6}{|l|}{ Total injury frequency rate (TIFR) } \\
\hline \multicolumn{6}{|l|}{ Lost time injury frequency rate (LTIFR) } \\
\hline \multicolumn{6}{|l|}{ RWC (restricted work cases) } \\
\hline \multicolumn{6}{|l|}{ Critical skills turnover } \\
\hline \multicolumn{6}{|l|}{ ART } \\
\hline \multicolumn{6}{|l|}{ TB (MDRTB, XDRTB), diagnoses } \\
\hline \multicolumn{6}{|l|}{ HIV/AIDS general, prevalence } \\
\hline \multicolumn{6}{|l|}{$\begin{array}{l}\text { Medical examinations, occupational health } \\
\text { screening, voluntary counselling and } \\
\text { testing }\end{array}$} \\
\hline \multicolumn{6}{|l|}{ post-retirement medical costs } \\
\hline \multicolumn{6}{|l|}{ Skills/shortages/skill development } \\
\hline \multicolumn{6}{|l|}{ Employee development } \\
\hline \multicolumn{6}{|l|}{$\begin{array}{l}\text { Bursary programme / Scholarships / } \\
\text { apprenticeships }\end{array}$} \\
\hline \multicolumn{6}{|l|}{$\begin{array}{l}\text { ABET (Adult basic education training), } \\
\text { literacy }\end{array}$} \\
\hline \multicolumn{6}{|l|}{ Housing/accommodation, living conditions } \\
\hline \multicolumn{6}{|l|}{$\begin{array}{l}\text { ESOP, Employee benefit } \\
\text { disclosure/package }\end{array}$} \\
\hline \multicolumn{6}{|l|}{$\begin{array}{l}\text { Transformation Advisory Committee (role, } \\
\text { membership)/process }\end{array}$} \\
\hline \multicolumn{6}{|l|}{ BEE, BEE ownership } \\
\hline \multicolumn{6}{|l|}{$\begin{array}{l}\text { HDSA ownership/empowerment/ } \\
\text { representation }\end{array}$} \\
\hline Local procurement/procurement policy & & & & & \\
\hline
\end{tabular}




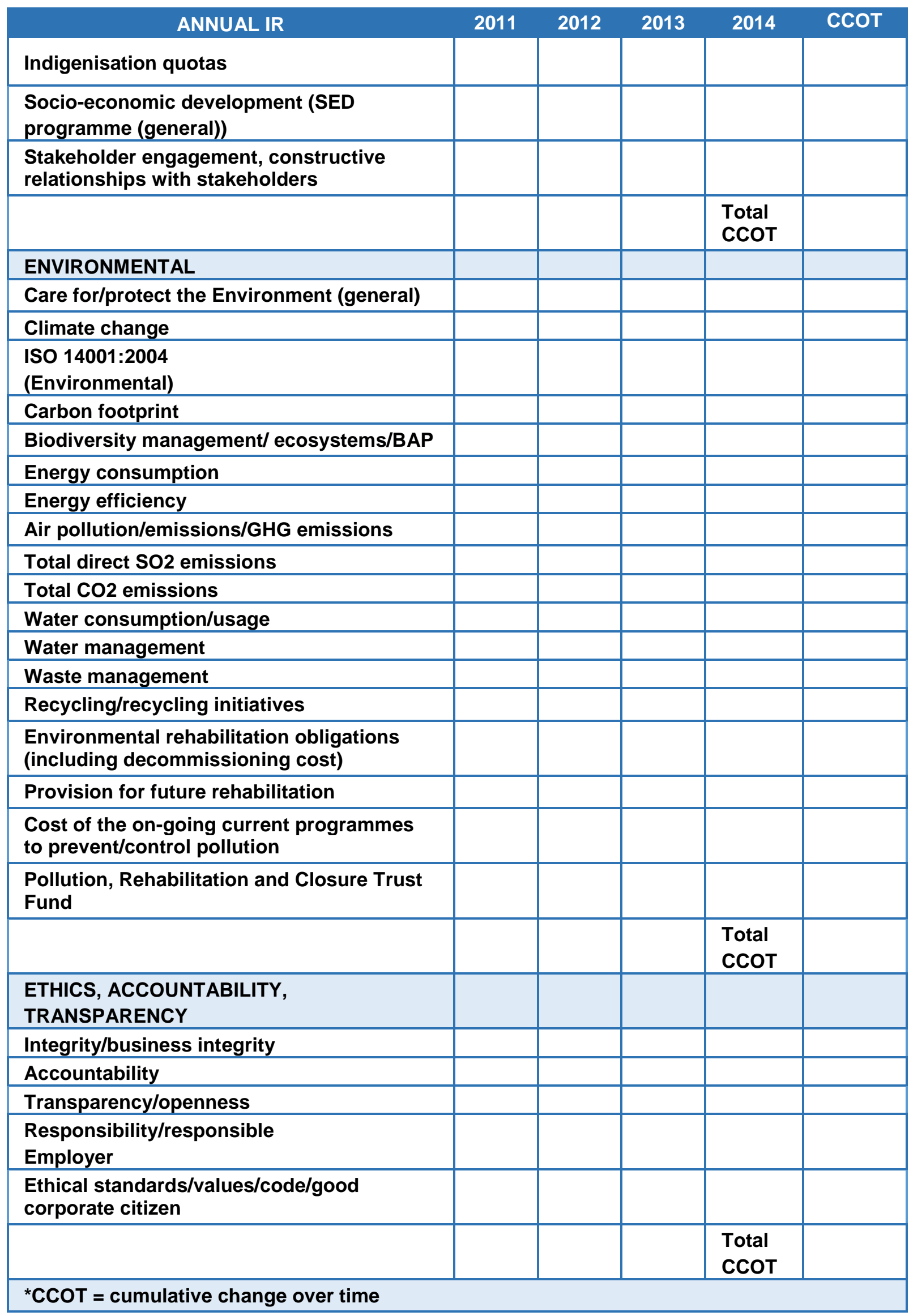

